\title{
ANALISIS RASIO KEUANGAN UNTUK MEMPREDIKSI \\ KEBANGKRUTAN PERUSAHAAN ROKOK \\ (Studi Subsektor Rokok yang Listing Di Bursa Efek Indonesia Tahun \\ 2010-2015)
}

\author{
Oleh : \\ Endang Purwanti \\ Dosen Tetap STIE AMA Salatiga \\ Mada Adi Wibowo \\ Dosen Tetap STIE AMA Salatiga
}

\begin{abstract}
Abstrak
Penelitian ini bertujuan untuk menganalisa rasio keuangan untuk memprediksi kebangkrutan perusahaan rokok (studi subsektor rokok yang listing di bursa efek indonesia tahun 2010-2015).

Populasi dalam penelitian ini adalah laporan keuangan perusahaan rokok yang listing di bursa efek indonesia tahun 2010-2015 Teknik pengambilan sampel adalah teknik penarikan purposif. Jenis data yang digunakan sekunder. Metode pengumpulan datanya adalah penelitian kepustakaan dan data yang telah dipublikasikan. Teknik analisis yang digunakan Analisis Z-Score.

Berdasarkan hasil analisis Altman Z-Score dengan acuan laporan keuangan maka hasil yang didapatkan dari tahun 2010-2015 menunjukkan dimana PT. Gudang Garam, Tbk prediksi posisi perusahaan adalah sehat meski hasil menurun dari tahun 2010-2013 tetapi PT. Gudang Garam, Tbk mampu meningkatkan kinerja keuangannya hingga tahun 2014-2015 dapat naik kembali. Sedangkan, PT. HM. Sampoerna dari tahun 2010-2015 prediksi posisi perusahaan sehat dan cenderung bergerak vertikal atau naik signifikan. Berbeda dengan PT. Bentoel Internasional Investama, Tbk dari tahun 2010-2015 turun signifikan dan hasil prediksi posisi perusahaan ditahun 2010-2012 adalah sehat dan tahun 2013-2015 ialah bangkrut.
\end{abstract}

Kata Kunci : rasio keuangan, prediksi kebangkrutan. 


\section{PENDAHULUAN}

Go-Public adalah kegiatan penawaran saham atau efek lainnya yang dilakukan oleh emiten (perusahaan) untuk menjual saham atau efek kepada masyarakat berdasarkan tata cara yang diatur oleh UU Pasar Modal dan Peraturan Pelaksanaannya.

Manfaat Go-Public dari sudut pandang Perusahaan :

1) Membuka Akses Perusahaan terhadap Sarana Pendanaan Jangka Panjang

2) Meningkatkan Nilai Perusahaan (Company Value)

3) Meningkatkan Image Perusahaan

4) Menumbuhkan Loyalitas Karyawan Perusahaan

5) Kemampuan untuk Mempertahankan Kelangsungan Usaha

6) Insentif Pajak

Bagi Investor manfaat dengan pencatatan saham perusahaan di Bursa Efek Indonesia, informasi dan berita tentang perusahaan akan sering diliput oleh media, penyedia data dan analis di perusahaan sekuritas. Publikasi secara cuma-cuma tersebut akan meningkatkan image perusahaan serta meningkatkan eksposur pengenalan atas produk-produk yang dihasilkan perusahaan. Hal ini akan menciptakan peluangpeluang baru dan pelanggan baru dalam bisnis perusahaan dimana manfaat ini merupakan Image perusahaan Go-Public. Oleh karenanya perusahaan go-public dituntut :

1. lebih terbuka, sehingga dapat memacu perusahaan untuk meningkatkan profesionalisme.

2. Perusahaan dituntut untuk dapat meningkatkan pertumbuhan perusahaan sehingga akan dapat meningkatkan citra perusahan.

3. Perusahaan harus mengikuti peraturan-peraturan yang ada dalam pasar modal mengenal kewajiban pelaporan

Sehingga perusahaan go-public berlomba-lomba mendapatkan kepercayaan masyarakat untuk mengembangkan sayap (ekspansi) melalui manfaat go-public tersebut.

Ada beberapa pengguna kepentingan didalam menganalisis perusahaan gopublic yang sehat yaitu dengan melihat laporan keuangan yang telah diterbitkan secara berkala oleh perusahaan yang bersangkutan (go-public). Oleh karena itu, perusahaan 
harus mencermati dan menganalisis kondisi keuangan perusahaan. Untuk mengetahui dengan tepat kondisi keuangan perusahaan maka diperlukan analisis terhadap media yang menyajikan laporan mengenai kondisi keuangan perusahaan. Media tersebut adalah berupa laporan keuangan perusahaan yang diterbitkan secara periodik bisa tahunan, semesteran, triwulanan, bulanan, mingguan bahkan harian. Laporan keuangan merupakan hasil dari proses akuntansi pada suatu periode waktu tertentu yang merupakan hasil pengumpulan dan pengolahan data keuangan untuk disajikan dalam dalam bentuk laporan keuangan atau ikhtisar lainnya yang dapat digunakan untuk membantu para pemakainya dalam mengambil keputusan. Informasi yang disajikan harus dapat dimengerti, tidak hanya oleh orang akuntansi tetapi juga untuk orang yang berlatar belakang pendidikan bukan akuntansi. Laporan keuangan haruslah bersifat umum dan disusun berdasarkan SAK (Standar Akuntansi Keuangan) agar dapat memenuhi kebutuhan pemakainya.

Laporan keuangan digunakan sebagai alat bantu dalam pengambilan keputusan, baik bagi pihak manajemen perusahaan, pihak stakeholder maupun pemerintah. Bagi pihak manajemen perusahaan, laporan keuangan digunakan sebagai alat pertanggujawaban manajemen kepada pemilik perusahaan serta menggambarkan tingkat efesiensi operasi dan prestasi manajemen dalam mengelola aktivitas perusahaan yang biasanya dilihat dari berapa besarnya laba yang diperoleh, sedangkan bagi pihak stakeholder laporan keuangan pada umumnya dipakai sebagai dasar pertimbangan dalam melakukan investasi atau pemberian kredit. Bagi pemerintah, laporan keuangan dapat digunakan sebagai alat ukur keberhasilan kebijakan ekonomi, pajak atau sebagai landasan dalam menetapkan kebijakan baru.

Kebangkrutan merupakan persoalan yang serius dan memakan biaya maka jika ada early warning system yang bisa mendeteksi potensi kebangkrutan sejak awal dimana manajemen akan sangat terbantu. Manajemen bisa melakukan perbaikanperbaikan yang diperlukan sendiri mungkin untuk menghindari kebangkrutan. Ada beberapa indikator yang bisa dipakai untuk memprediksi kebangkrutan. Indikator tersebut bisa berupa indikator internal (dari dalam perusahaan) dan indikator eksternal (dari luar perusahaan). Indikator internal perusahaan antara lain aliran kas perusahaan, strategi perusahaan, laporan keuangan, trend penjualan dan kemampuan manajemen. Sedangkan, indikator eksternal perusahaan bisa diambil dari pasar keuangan, 
informasi dari pihak yang berkepetingan seperti pemasok, dealer dan konsumen. (Hanafi, 2004:654).

Salah satu indikator yang bisa dipakai untuk mengetahui tingkat kebangkrutan perusahaan adalah indikator keuangan. Kebanyakan penyebab kebangkrutan dimulai dari adanya kesulitan keuangan. Prediksi kesulitan keuangan ini salah satunya dikemukakan oleh seorang Professor di New York University bernama Edward Altman yang disebut dengan Altman Z-Score. Rumus ini merupakan hasil penelitian yang dilakukan terhadap perusahaan-perusahaan yang mengalami kebangkrutan di Amerika Serikat. Komponen-komponen yang ada pada Altman Z-Score adalah modal kerja, aktiva, laba sebelum pajak, laba ditahan, penjualan dan nilai pasar ekuitas.

Dalam hal ini pemilihan satu perusahaan pada penelitian ini peneliti memilih untuk melakukan penelitian pada perusahaan yang bergerak pada bidang industri rokok. Pilihan ini dirasa cocok dengan penggunaan analisis laporan keuangan yang cenderung lebih akurat untuk memprediksi tingkat kebangkrutan pada industri rokok dengan tingkat modal yang tidak terpaut jauh. Selain itu, perusahaan-perusahaan tersebut juga merupakan perusahaan terbuka yang terdaftar di Bursa Efek Indonesia (BEI).

Berdasarkan uraian diatas peneliti tertarik untuk melakukan penelitian mengenai bagaimana prediksi kebangkrutan di perusahaan rokok yang terdaftar di Bursa Efek Indonesia . Maka dalam penelitian ini penulis mengambil judul Analisis Rasio Keuangan Untuk Memprediksi Kebangkrutan Perusahaan Rokok (Studi Subsektor Rokok yang Listing di Bursa Efek Indonesia Tahun 2010-2015).

\section{RUMUSAN MASALAH}

Berdasarkan uraian diatas maka apakah dengan menggunakan metode Z-Score dapat mengindikasikan perusahaan rokok yang mengalami kebangkrutan dan yang diindikasi tidak mengalami kebangkrutan selama kurun waktu 2010-2015. 


\section{TUJUAN PENELITIAN}

Tujuan penelitian ini adalah untuk dapat mengetahui indikasi perusahaan rokok selama kurun waktu 2010-2015 diindikasi bangkrut dan atau selama kurun waktu 2010-2015 diindikasi tidak bangkrut.

\section{LANDASAN TEORI}

\section{Laporan Keuangan}

Laporan keuangan pada hakekatnya merupakan hasil dari proses akuntansi yang dapat digunakan untuk mengkomunikasikan data keuangan kepada pihak yang berkepentigan. Keputusan ekonomi yang diambil pemakai laporan keuangan memerlukan evaluasi atas kemampuan perusahaan dalam menghasilkan kas (dan setara kas) dan waktu serta kepastian dari hasil tersebut. Misalnya, kemampuan perusahaan untuk memenuhi kewajiban-kewajiban hutangnya.

Pengertian laporan keuangan menurut SAK No.1 (2002:2) pengertian laporan keuangan adalah : laporan keuangan merupakan bagian dari proses pelaporan keuangan yang lengkap, biasanya meliputi neraca, laporan laba-rugi, laporan posisi keuangan (yang dapat disajikan dalam beberapa cara seperti : laporan arus kas atau laporan arus dana), catatan dan laporan lain serta materi penjelasan yang merupakan bagian integral dari laporan keuangan. Disamping itu juga, termasuk skedul dan informasi tambahan yang berkaiatan dengan laporan tersebut. Misalnya: informasi keuangan segmen industri dan geografis serta pengungkapan pengaruh perubahan harga.

Laporan keuangan menurut Myer dalam Munawir (2004 : 5) adalah dua daftar yang disusun oleh Akuntan pada akhir periode suatu perusahaan. Kedua daftar itu adalah daftar neraca atau daftar posisi keuangan dan daftar pendapatan atau daftar rugi-laba. Pada akhir-akhir ini sudah menjadi kebiasaan bagi perseroan-perseroan untuk menambahkan daftar ketiga yaitu daftar surplus atau daftar laba yang tak dibagikan (laba ditahan).

\section{Kinerja Keuangan}

Menurut Jumingan (2006:239) kinerja keuangan adalah gambaran kondisi keuangan perusahaan pada suatu periode tertentu baik menyangkut aspek 
perhimpunan dana maupun penyaluran dana yang biasanya diukur dengan indikator kecukupan modal, likuiditas dan profotabilitas.

Menurut Habib (2008:91) kinerja keuangan dapat dikatakan sebagai hasil yang dicapai oleh perusahaan atas berbagai aktivitas yang dilakukan dengan mendayagunakan snmber keuangan yang tersedia.

\section{Analisis Rasio Keuangan}

Menurut Hanafi dan Halim (2007:76) Rasio-rasio keuangan pada dasarnya disusun dengan menggabungkan angka-angka didalam atau antara laporan laba-rugi dan neraca. Dengan cara rasio semacam itu diharapkan pengaruh perbedaan ukuran akan hilang dan membuat ukuran bukan dalam angka absolut tetapi dalam angka relatif.

Menurut Kasmir (2009 : 106) Untuk mengukur kinerja keuangan perusahaan dengan menggunakan rasio-rasio keuangan, dapat dilakukan dengan beberapa rasio keuangan. Setiap rasio keuangan memiliki tujuan, kegunaan dan arti tertentu. Kemudian, setiap hasil dari rasio yang diukur diinterpretasikan sehingga menjadi berarti bagi pengambilan keputusan.

\section{1) Rasio Likuditas}

Menurut Darsono dan Ashari (2005 : 74) Rasio likuiditas adalah rasio yang bertujuan untuk mengetahui kemampuan perusahaan dalam membayar kewajiban jangka pendek. Ukuran yang sering digunakan adalah Current Ratio (CR) dan Quick Ratio (QR).

a) Current Ratio (CR) yaitu kemampuan aktiva lancar perusahaan dalam memenuhi kewajiban jangka pendek.

$$
\text { Current Ratio }=\frac{\text { Aktiva Lancar }}{\text { Utang Lancar }}
$$

b) Quick Ratio (QR) yaitu rasio yang mengukur kemampuan aktiva lancar dikurangi persediaan untuk membayar kewajiban lancar.

$$
\text { Quick Ratio }=\frac{\text { Aktiva Lancar }- \text { Persediaan }}{\text { Utang Lancar }}
$$




\section{2) Rasio Profitabilitas}

Menurut Hanafi (2004:42) Rasio Profitabilitas merupakan rasio yang dapat digunakan untuk menilai kemampuan perusahaan dalam memperoleh keuntungan. Rasio-rasio yang dapat digunakan untuk menilai profitabilitas yaitu Profit Margin, Return On Asset (ROA) dan Return On Equity (ROE).

a) Profit Margin menghitung sejauh mana kemampuan perusahaan menghasilkan laba bersih pada tingkat penjualan tertentu.

\section{Profit Margin $=\frac{\text { Laba Bersih }}{\text { Penjualan }}$}

b) Return On Asset (ROA) mengukur kemampuan perusahaan menghasilkan laba bersih berdasarkan tingkat aset tertentu.

$$
\text { ROA }=\frac{\text { Laba Bersih }}{\text { Total Aset }}
$$

c) Return On Equity (ROE) mengukur kemampuan perusahaan menghasilkan laba bersih berdasarkan modal tertentu.

$$
\text { ROE }=\frac{\text { Laba Bersih }}{\text { Modal Saham }}
$$

\section{3) Rasio Aktivitas}

Menurut Umar (2001 : 112) merupakan rasio yang digunakan menentukan penilaian efektivitasnya perusahaan untuk menghasilkan penjualan. Terdapat 4 perhitungan rasio aktivitas, yaitu: perputaran persediaan, perputaran aktiva tetap, perputaran total aktiva dan rata-rata umur piutang.

a) Perputaran Persediaan yaitu keefektifaan dan keefisienan perusahaan untuk mengatur investasinya dalam persediaan direfleksikan dalam beberapa kali persediaan itu diputar selama satu periode tertentu dalam satu tahun.

\section{Perputaran Persediaan $=\frac{\text { Persediaan }}{\frac{H P P}{365}}$}

b) Perputaran Aktiva Tetap berguna untuk mengukur efesiensi perusahaan dalam penggunaan aktiva tetap guna menghasilkan penjualan. Perputaran 
total aktiva digunakan untuk mengukur efesiensi perusahaan dalam pemakaian total aktivanya untuk menghasilkan penjualan.

Perputaran Aktiva Tetap $=\frac{\text { Penjualan }}{\text { Aktiva Tetap }}$

c) Rata-rata umur piutang menyatakan seberapa cepat perusahaan dapat menagih piutang dagangnya sehingga memperoleh kas.

Rata-rata umur piutang $=\frac{\text { Piutang Dagang }}{\frac{\text { Penjualan }}{360}}$

d) Perputaran Total Aktiva menyatakan efektivitas penggunaan total aktiva.

Perputaran Total Aktiva $=\frac{\text { Penjualan }}{\text { Total Aktiva }}$

\section{4) Rasio Pasar}

Menurut Hanafi (2004:43) Rasio pasar menggunakan harga pasar saham perusahaan relatif terhadap nilai bukunya. Ada beberapa rasio yang bisa dihitung, yaitu Price Earnig Ratio (PER), Dividend Yield, dan pembayaran Dividen (Dividend pay-out Ratio).

a) Price Earning Ratio (PER) mengukur harga saham relatif terhadap earning atau pendapatannya.

$$
\text { PER }=\frac{\text { Harga Pasar per lembar }}{\text { Laba bersih per lembar }}
$$

b) Dividend Yield mengukur harga saham relatif terhadap return atau pendapatannya yang akan diterima investor termasuk capital gain atau capital loss.

$$
\text { Dividend Yield }=\frac{\text { Dividend per lembar }}{\text { Harga pasar per lembar }}
$$

\section{5) Rasio Solvabilitas}

Menurut Prastowo dan Julianty (2005:89) Rasio solvabilitas menggambarkan kemampuan perusahaan memenuhi kewajiban jangka panjangnya. Rasio yang digunakan untuk mengukur kemampuan ini yaitu Debt to Equity Ratio (DER), Rasio Times Interest Earned (TIE). 
a) Debt to Equity Ratio (DER) merupakan keseimbangan proporsi antara aktiva yang didanai oleh kreditor dan yang didanai oleh pemilik perusahaan.

$$
\text { DER }=\frac{\text { Total Hutang }}{\text { Total Aset }}
$$

b) Times Interest Earned (TIE) untuk mengukur kemampuan operasi perusahaan dalam memberikan proteksi kepada kreditor jangka panjang khususnya dalam membayar bunga.

$$
\mathrm{TIE}=\frac{\text { Laba sebelum bunga dan pajak }}{\text { Beban bunga }}
$$

\section{b) Analisis Kebangkrutan}

Menurut Hanafi (2010:638) menyatakan "Perusahaan dapat dikatakan bangkrut apabila perusahaan itu mengalami kesulitan ringan (seperti masalah likuiditas) dan sampai kesulitan yang lebih serius yaitu solvabel (utang lebih besar dibandingkan asset)".

Menurut Weston \& Copeland (1997 : 510) menyebutkan bahwa kebangkrutan adalah suatu kegagalan yang terjadi dalam perusahaan apabila perusahaan tersebut mengalami:

1) Kegagalan Ekonomi (Economic Distressed) kegagalan dalam arti ekonomis bahwa perusahaan tidak mampu lagi menutup biayanya yang berarti bahwa tingkat labanya lebih kecil dari pada biaya modalnya.

2) Kegagalan Keuangan (Financial Distressed) insolvensi memiliki dua bentuk yakni default teknis yang terjadi bila suatu perusaahaan gagal memenuhi salah satu atau lebih kondisi didalam ketentuan hutangnya seperti rasio aktiva lancar dengan hutang lancar yang ditetapkan serta kegagalan keuangan atau ketidakmampuan teknik (Technical Insolvency) yang terjadi apabila perusahaan tidak mampu memenuhi kewajibannya pada waktu yang telah ditentukan.

Model prediksi kebangkrutan multivariate yang cukup terkenal dan menjadi pioner adalah model kebangkrutan yang dikembangkan oleh Altman (1969). Dimana Z merupakan skor kebangkrutan sedangkan X1.......Xn adalah variabel bebas. Model yang dikembangkan oleh Altman menghasilkan persamaan sebagai berikut:

$$
\mathrm{Zi}=1,2 \mathrm{X1}+1,4 \mathrm{X2}+3,3 \mathrm{X3}+0,6 \mathrm{X} 4+1,0 \times 5
$$


Dimana :

$\mathrm{X} 1=($ Aktiva Lancar - Utang Lancar $) /$ Total Aktiva

X2 = Laba yang Ditahan / Total Aset

X3 = Laba sebelum Bunga dan Pajak / Total Aset

X4 = Nilai Pasar Saham Biasa dan Preferen / Nilai Buku Total

Utang

X5 = Penjualan / Total Aset

Dengan kriteria penilaian sebagai berikut:

1) $Z$-Score $>2,99$ dikategorikan sebagai perusahaan yang sehat sehingga tidak mengalami kesulitan keuangan.

2) $1,81<Z$-Score $<2,99$ berada didaerah abu-abu sehingga dikaterogikan sebagai perusahaan yang memiliki kesulitan keuangan namun memungkinkan terselamatkan dan kemungkinan bangkrut sama besarnya tergantung keputusan kebijaksanaan manajemen perusahaan sebagai pengambil keputusan.

3) Z-Score $<1,81$ dikategorikan sebagai perusahaan yang memiliki kesulitan keuangan yang sangat besar dan beresiko tinggi sehingga kemungkinan bangkrutnya sangat besar.

\section{c) Kerangka Pemikiran}

Penelitian ini dilakukan untuk memperoleh gambaran yang jelas dan menunjukkan arah secara sistematis mengenai pemecahan masalah yang akan dihadapi. Kerangka pemikiran dalam penelitian ini dapat digambarkan sebagai berikut:

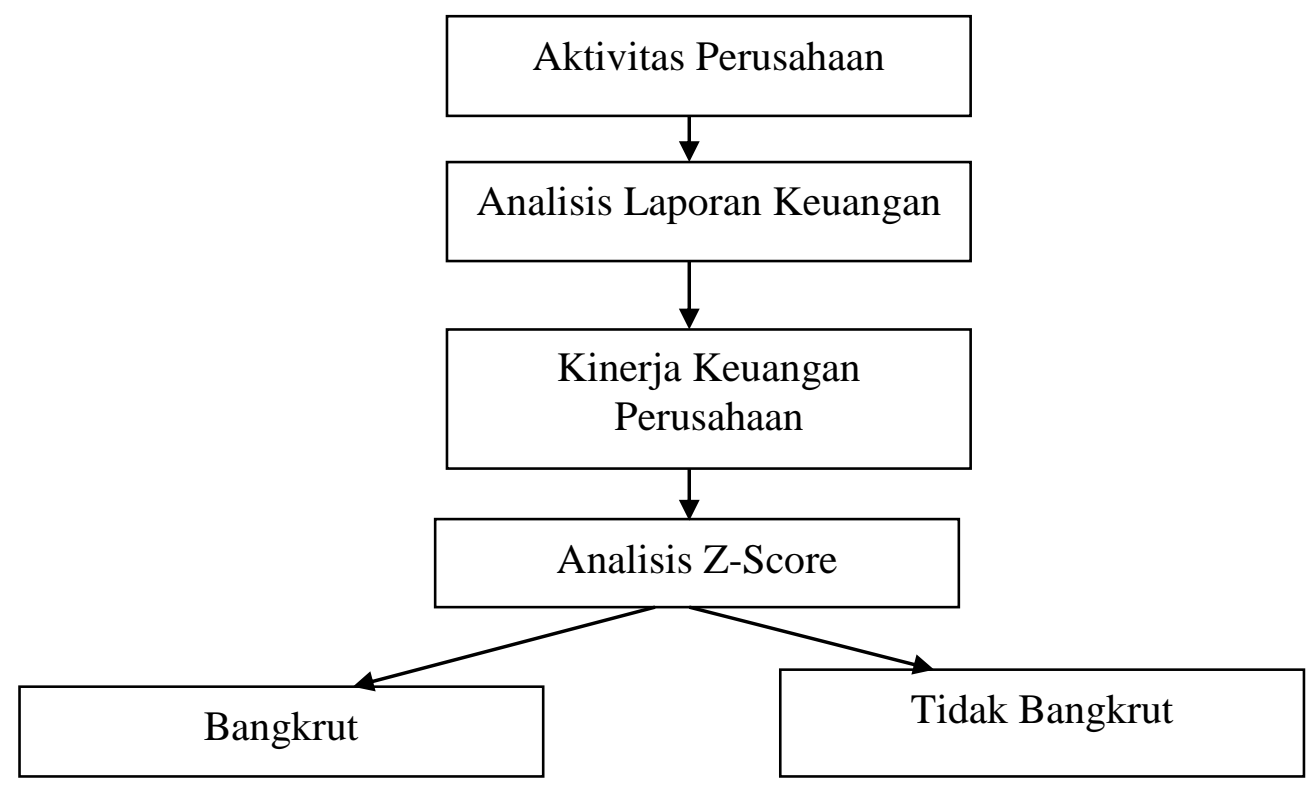




\section{METODE ANALISIS DATA}

Langkah-langkah yang dilakukan dalam proses analisis ini adalah sebagai berikut:

1) Menghitung $X_{1}, X_{2}, X_{3}, X_{4}$ dan $X_{5}$ masing-masing perusahaan tiap tahunnya.

2) Menghitung Z-Score berdasarkan perhitungan matematika sebagai berikut:

\section{$Z=1,2 X_{1}+1,4 X_{2}+3,3 X_{3}+0,6 X_{4}+1,0 X_{5}$}

3) Mengklasifikasikan kondisi perusahaan sesuai dengan titik cut off, yaitu sebagai berikut:

a. $\mathrm{Z}<1,81$ perusahaan masuk dalam kategori bangkrut

b. $1,81<\mathrm{Z}<2,99$ perusahaan masuk dalam kategori rawan

c. $Z>2,9$ perusahaan masuk dalam kategori sehat

d. Membandingkan hasil penerapan metode Altman pada subsektor rokok yang listing.

Mengambil kesimpulan kinerja keuangan perusahaan dan memprediksi kebangkrutan dari hasil analisis data yang menggunakan metode Altman.

\section{ANALISIS DATA}

1. PT. Gudang Garam, Tbk

\section{Perhitungan Nilai Z-Score PT. Gudang Garam, Tbk}

\begin{tabular}{|c|c|c|c|c|c|c|c|c|}
\hline \multirow[b]{2}{*}{ Tahun } & \multicolumn{5}{|c|}{$Z=1,2 X_{1}+1,4 X_{2}+3,3 X_{3}+0,6 X_{4}+1,0 X_{5}$} & \multirow{2}{*}{$\begin{array}{c}\text { Nilai } \\
\text { Z- } \\
\text { Score }\end{array}$} & \multirow[b]{2}{*}{ Perubahan } & \multirow[b]{2}{*}{ Prediksi } \\
\hline & $\mathrm{X}_{1}$ & $\mathrm{X}_{2}$ & $\mathrm{X}_{3}$ & $\mathrm{X}_{4}$ & $\mathrm{X}_{5}$ & & & \\
\hline 2010 & 0,469 & 0,656 & 0,183 & 8,304 & 1,226 & 8,293 & - & SEHAT \\
\hline 2011 & 0,431 & 0,598 & 0,169 & 8,318 & 1,072 & 7,975 & $(-)-4 \%$ & SEHAT \\
\hline 2012 & 0,389 & 0,614 & 0,133 & 7,366 & 1,181 & 7,367 & $(-)-8 \%$ & SEHAT \\
\hline 2013 & 0,286 & 0,557 & 0,117 & 3,831 & 1,092 & 4,900 & $(-)-33 \%$ & SEHAT \\
\hline 2014 & 0,253 & 0,551 & 0,124 & 4,697 & 1,120 & 5,422 & $(+) 11 \%$ & SEHAT \\
\hline 2015 & 0,292 & 0,581 & 0,136 & 4,165 & 1,108 & 5,219 & $(-)-4 \%$ & SEHAT \\
\hline
\end{tabular}

Berdasarkan tabel perhitungan nilai Z-Score pada PT. Gudang Garam, Tbk pada tahun 2010 menunjukkan posisi sehat dengan nilai Z-Score 8,293, tahun 2011 
nilai Z-Score menurun sebesar 7,975 atau sekitar $-4 \%$ yang juga menunjukkan perusahaan berada pada posisi sehat, tahun 2012 nilai Z-Score menurun sebesar 7,367 atau sekitar -8\% dan perusahaan berada pada posisi sehat, tahun 2013 nilai Z-Score menurun sebesar 4,900 atau sekitar $-33 \%$ dan perusahaan berada pada posisi sehat, tahun 2014 nilai Z-Score menunjukkan kenaikan sebesar 5,422 atau sekitar 11\% dan perusahaan berada pada posisi sehat serta tahun 2015 nilai Z-Score menujukkan penurunan sebesar 5,219 atau $-4 \%$ dan perusahaan berada pada posisi sehat.

2. HM. Sampoerna, Tbk

Perhitungan Nilai Z-Score PT. HM. Sampoerna, Tbk

\begin{tabular}{|c|c|c|c|c|c|c|c|c|}
\hline \multirow[b]{2}{*}{ Tahun } & \multicolumn{5}{|c|}{$Z=1,2 X_{1}+1,4 X_{2}+3,3 X_{3}+0,6 X_{4}+1,0 X_{5}$} & \multirow{2}{*}{$\begin{array}{c}\text { Nilai } \\
\text { Z- } \\
\text { Score }\end{array}$} & \multirow[b]{2}{*}{ Perubahan } & \multirow[b]{2}{*}{ Prediksi } \\
\hline & $\mathrm{X}_{1}$ & $\mathrm{X}_{2}$ & $\mathrm{X}_{3}$ & $\mathrm{X}_{4}$ & $\mathrm{X}_{5}$ & & & \\
\hline 2010 & 0,292 & 0,445 & 0,426 & 11,877 & 2,114 & 11,619 & - & SEHAT \\
\hline 2011 & 0,328 & 0,471 & 0,563 & 18,632 & 2,728 & 16,818 & $(+) 45 \%$ & SEHAT \\
\hline 2012 & 0,352 & 0,462 & 0,510 & 20,291 & 2,538 & 17,465 & (+) $4 \%$ & SEHAT \\
\hline 2013 & 0,333 & 0,474 & 0,529 & 20,644 & 2,738 & 17,934 & (+) $3 \%$ & SEHAT \\
\hline 2014 & 0,253 & 0,435 & 0,483 & 20,217 & 2,843 & 17,480 & $(-)-3 \%$ & SEHAT \\
\hline 2015 & 0,665 & 0,275 & 0,366 & 71,962 & 2,343 & 47,911 & (+) $174 \%$ & SEHAT \\
\hline
\end{tabular}

Berdasarkan tabel perhitungan nilai Z-Score pada PT. HM. Sampoerna, Tbk pada tahun 2010 menunjukkan posisi sehat dengan nilai Z-Score 11,619, tahun 2011 nilai Z-Score mengalami kenaikan sebesar 16,818 atau sekitar $45 \%$ yang juga menunjukkan perusahaan berada pada posisi sehat, tahun 2012 nilai Z-Score mengalami kenaikan sebesar 17,465 atau sekitar 4\% dan perusahaan berada pada posisi sehat, tahun 2013 nilai Z-Score mengalami kenaikan sebesar 17,934 atau sekitar 3\% dan perusahaan berada pada posisi sehat, tahun 2014 nilai Z-Score menunjukkan penurunan sebesar 17,480 atau sekitar $-3 \%$ dan perusahaan berada pada posisi sehat serta tahun 2015 nilai Z-Score menujukkan kenaikan sebesar 47,911 atau 174\% dan perusahaan berada pada posisi sehat. 
3. PT. Bentoel Internasional Investama, Tbk

Perhitungan Nilai Z-Score

PT. Bentoel Internasional Investama, Tbk

\begin{tabular}{|l|c|c|c|c|c|c|c|l|}
\hline \multirow{2}{*}{ Tahun } & \multicolumn{2}{|c|}{$\mathbf{Z}=\mathbf{1 , 2} \mathbf{X}_{\mathbf{1}}+\mathbf{1 , 4} \mathbf{X}_{\mathbf{2}}+\mathbf{3 , 3} \mathbf{X}_{\mathbf{3}}+\mathbf{0 , 6} \mathbf{X}_{\mathbf{4}}+\mathbf{1 , 0} \mathbf{X}_{\mathbf{5}}$} & Nilai & & \multirow{2}{*}{ Prediksi } \\
\cline { 2 - 8 } & $\mathrm{X}_{1}$ & $\mathrm{X}_{2}$ & $\mathrm{X}_{3}$ & $\mathrm{X}_{4}$ & $\mathrm{X}_{5}$ & $\begin{array}{c}\text { Z- } \\
\text { Score }\end{array}$ & Perubahan & S \\
\hline 2010 & 0,449 & 0,433 & 0,248 & 1,253 & 1,816 & 4,199 & - & SEHAT \\
\hline 2011 & 0,086 & 0,36 & 0,254 & 0,84 & 1,59 & 3,13 & $(-)-25 \%$ & SEHAT \\
\hline 2012 & 0,302 & 0,263 & $(0,205)$ & 1,729 & 1,42 & 3,509 & $(+) 12 \%$ & SEHAT \\
\hline 2013 & 0,115 & 0,038 & $(0,419)$ & 0,044 & 1,26 & 1,038 & $(-)-70 \%$ & BANGKRUT \\
\hline 2014 & 0,014 & $(0,266)$ & $(0,515)$ & 0,004 & 1,339 & 0,576 & $(-)-45 \%$ & BANGKRUT \\
\hline 2015 & 0,392 & $(0,409)$ & $(0,505)$ & 0,042 & 1,327 & 0,847 & $(+) 47 \%$ & BANGKRUT \\
\hline
\end{tabular}

Berdasarkan tabel perhitungan nilai Z-Score pada PT. Bentoel Internasional Investama, Tbk pada tahun 2010 menunjukkan posisi sehat dengan nilai Z-Score 4,199, tahun 2011 nilai Z-Score mengalami penurunan sebesar 3,130 atau sekitar 25\% yang juga menunjukkan perusahaan berada pada posisi sehat, tahun 2012 nilai ZScore mengalami kenaikan sebesar 3,509 atau sekitar 12\% dan perusahaan berada pada posisi sehat, tahun 2013 nilai Z-Score mengalami penurunan sebesar 1,038 atau sekitar -70\% dan perusahaan berada pada posisi bangkrut, tahun 2014 nilai Z-Score menunjukkan penurunan sebesar 0,576 atau sekitar $-45 \%$ dan perusahaan berada pada posisi bangkrut serta tahun 2015 nilai Z-Score menujukkan kenaikan sebesar 0,847 atau $47 \%$ dan perusahaan berada pada posisi bangkrut.

Analisa PT. Gudang Garam, Tbk dari tahun 2010-2015 data menyebutkan bahwa nilai Z-Score berada dalam prediksi sehat, tetapi jika PT. Gudang Garam tidak dapat meningkatkan kinerjanya maka nilai Z-Score pasti akan menurun. Seperti yang terlihat dari data 2010 ke 2015 mengalami penurunan dari 8,293; 7,975; 7,367; 4,900; 5,422 dan 5,219 hanya progres dari tahun 2013 ke 2014 yang mengalami kenaikan saja maka dengan adanya hasil analisis ini PT. Gudang Garam, Tbk mampu untuk memperhatikan betul kinerja keuangannya seperti meningkatkan penjualan dan meminimalkan hutang lancarnya. 
Sedangkan analisa PT. HM. Sampoerna, Tbk data menyebutkan selama 6 tahun dari 2010-2015 menyebutkan bahwa prediksi dari nilai Z-Score sehat dan progresnya baik sekali dimana nilai Z-Score dari tahun 2010-2015 adalah 11,619; 16,$818 ; 17,465 ; 17,934 ; 17,480$ dan 47,911 dimana setiap tahunnya naik dan ditahun 2015 PT. HM. Sampoerna mampu untuk menggenjot kinerjanya sehingga perubahan dari tahun 2014-2015 ialah 174\% . hal ini tentunya dapat dipertahankan bahkan ditingkatkan lagi dari segi mengurangi ketergantungan akan hutang lancarnya dan mendapat trust dari investor yang mana saham PT. HM. Sampoerna, Tbk meningkat sehingga PT. HM. Sampoerna mampu bersaing didunia industri rokok.

Terakhir analisa dari PT. Bentoel Internasional Investama, Tbk menyebutkan ditahun 2010-2015 menyebutkan bahwa di tiga tahun mulai dari tahun 2010-2012 posisi Z-Score dalam keadaan sehat tetapi keadaan berubah sangat tajam kearah posisi bangkrut pada tahun 2013-2015. Maka pihak perusahaan PT. Bentoel Internasional Investama, Tbk haruslah meningkatkan penjualannya, mengurangi hutang lancarnya dan berupaya mendapat trust dari investor agar menanamkan sahamnya di PT. Bentoel Internasional Investama, Tbk sehingga mampu meningkatkan kinerja keuangannya.

\section{SIMPULAN}

Hasil analisis data yang membahas mengenai bagaimana prediksi kebangkrutan pada ketiga perusahaan yang bergerak di industri rokok yaitu PT. Gudang Garam, Tbk ; PT. HM. Sampoerna, Tbk; PT. Bentoel Internasional Investama, Tbk dapat ditarik kesimpulan sebagai berikut:

\section{PT. Gudang Garam, Tbk}

PT. Gudang Garam, Tbk pada tahun 2010 menunjukkan posisi sehat dengan nilai Z-Score 8,293, tahun 2011 nilai Z-Score menurun sebesar 7,975 atau sekitar -4\% yang juga menunjukkan perusahaan berada pada posisi sehat, tahun 2012 nilai ZScore menurun sebesar 7,367 atau sekitar $-8 \%$ dan perusahaan berada pada posisi sehat, tahun 2013 nilai Z-Score menurun sebesar 4,900 atau sekitar $-33 \%$ dan perusahaan berada pada posisi sehat, tahun 2014 nilai Z-Score menunjukkan kenaikan sebesar 5,422 atau sekitar $11 \%$ dan perusahaan berada pada posisi sehat serta tahun 2015 nilai Z-Score menujukkan penurunan sebesar 5,219 atau -4\% dan perusahaan berada pada posisi sehat. 
2. PT. HM. Sampoerna, Tbk

PT. HM. Sampoerna, Tbk pada tahun 2010 menunjukkan posisi sehat dengan nilai Z-Score 11,619, tahun 2011 nilai Z-Score mengalami kenaikan sebesar 16,818 atau sekitar $45 \%$ yang juga menunjukkan perusahaan berada pada posisi sehat, tahun 2012 nilai Z-Score mengalami kenaikan sebesar 17,465 atau sekitar 4\% dan perusahaan berada pada posisi sehat, tahun 2013 nilai Z-Score mengalami kenaikan sebesar 17,934 atau sekitar 3\% dan perusahaan berada pada posisi sehat, tahun 2014 nilai Z-Score menunjukkan penurunan sebesar 17,480 atau sekitar $-3 \%$ dan perusahaan berada pada posisi sehat serta tahun 2015 nilai Z-Score menujukkan kenaikan sebesar 47,911 atau $174 \%$ dan perusahaan berada pada posisi sehat.

3. PT. Bentoel Internasional Investama, Tbk

PT. Bentoel Internasional Investama, Tbk pada tahun 2010 menunjukkan posisi sehat dengan nilai Z-Score 4,199, tahun 2011 nilai Z-Score mengalami penurunan sebesar 3,130 atau sekitar -25\% yang juga menunjukkan perusahaan berada pada posisi sehat, tahun 2012 nilai Z-Score mengalami kenaikan sebesar 3,509 atau sekitar 12\% dan perusahaan berada pada posisi sehat, tahun 2013 nilai Z-Score mengalami penurunan sebesar 1,038 atau sekitar $-70 \%$ dan perusahaan berada pada posisi bangkrut, tahun 2014 nilai Z-Score menunjukkan penurunan sebesar 0,576 atau sekitar $-45 \%$ dan perusahaan berada pada posisi bangkrut serta tahun 2015 nilai Z-Score menujukkan kenaikan sebesar 0,847 atau $47 \%$ dan perusahaan berada pada posisi bangkrut.

\section{SARAN}

Saran untuk ketiga perusahaan yaitu PT. Gudang Garam, Tbk ; PT. HM. Sampoerna, Tbk; PT. Bentoel Internasional Investama, Tbk yang bergerak di industri rokok adalah :

1. Perusahaan harus tetap meningkatkan kinerja keuangannya agar terhindar dari resiko kebangkrutan yaitu dengan cara meningkatkan volume penjualannya.

2. Meningkatkan efesiensi penggunaan sumber daya yang dimiliki oleh perusahaan seperti memaksimalkan penggunaan aset agar tidak ada sumber daya yang menganggur. Baik yang telah atau yang mengalami kekurangan trust dalam mendapatkan modal saham supaya memperhatikan betul calon investor dan 
investor yang akan membantu dalam meningkatkan modal yang akan digunakan dalam operasional perusahaan.

\section{DAFTAR PUSTAKA}

Darsono, Ashari, 2005. Pedoman Praktis Memahami Laporan Keuangan. Andi Offset. Yogyakarta.

Hanafi, Mamduh. 2004. Manajemen Keuangan Edisi Kedua. BPFE-Yogyakarta. Yogyakarta.

Hanafi, Mamduh. Halim, Abdul. 2005. Analisis Laporan Kuangan Edisi Kedua. UPP AMP YKPM. Yogyakarta.

Indriantoro. Nur, Bambang Supomo. 2002. Metodologi Penelitian Bisnis. BPFE Yogyakarta. Yogyakarta.

Jumingan. 2006. Analisis Laporan Keuangan. PT. Bumi Aksara. Jakarta.

Kasmir. 2009. Analisis Laporan Keuangan. PT. Raja Grafindo Persada. Jakarta.

Sukhemi. Analisis Rasio Keuangan untuk Memprediksi Kebangkrutan.

Sofyan. Syafri. Harahap. 2007. Teori Akuntansi Edisi Revisi. PT. Raja Grafindo Persada. Jakarta.

Umar, Husein. 2001.Riset Akuntansi. PT. Gramedia Pustaka Utama. Jakarta

W. Tambunan, Rafles,dkk. 2015. Analisis Kebangkrutan Perusahaan dengan Menggunakan Metode Altman (Z-Score) (Studi pada Subsektor Rokok yang dilisting dan Perusahaan yang delisting di Bursa Efek Indonesia Tahun 20092013).

Yuliyanti, Erlita. 2012. Analisis Rasio Keuangan untuk Memprediksi Kebangkrutan Perusahaan pada PT. Kimia Farma (Persero), Tbk. Periode 2006-2010.

http://www.bentoelgroup.com/group/sites/BAT_A5EEYP.nsf/vwPagesWebLive/DOA $\underline{4 \text { SGGS }}$

http://syafrizalsetiabudi.blogspot.co.id/2013/02/pengertian-go-public.html http://gopublic.idx. manfaat go public. Diperoleh 27 Desember 2016

https://Gudang garam tbk. Laporan keuangan tahunan. Diperoleh 27 Desember 2016 http://www.sampoerna.com/id_id/investor_information/disclosures_and_reports/pages lannual_reports.aspx

http://www.gudanggaramtbk.com/investor/laporan_tahunan http://Bentoelgroup. Laporan Keuangan Tahunan. Diperoleh 11 Januari 20117 